\title{
Effect of Educational Programs on the Knowledge, Attitude, and Practice of Type 1 Diabetic Patients about Proper Sharps Disposal at Home.
}

\author{
${ }^{1}$ Magda Aly Mohamed, ${ }^{2}$ Omaima Mohamed Elalem $\&^{3}$ Mona Abd Elsabour \\ ${ }^{1,2,3}$ Department of Family \& community health Nursing, Faculty of Nursing, Port said \\ University Egypt.
}

\begin{abstract}
Background: The safe management of needles, syringes and other sharps generated by non-clinical activities is an emerging issue for local councils. Aim: the aim of the present study was to evaluate effect of educational programs on the knowledge, attitude, and practice of type 1 diabetic patients about proper sharps disposal at home. Subjects and methods: a quasi-experimental design was utilized in this study. Setting: This study was conducted in four primary health care centers in Port-Said city. Sample: All diabetic patients with type 1 diabetes mellitus attending the prementioned setting in the period of three months were included in the study, total number were 100 patients. Methods: Data collected by using three tools. Tool 1: includes Socio-demographic Data and patient's knowledge of safe disposal of insulin syringe at home. Tool II: patient's attitude of safe disposal of insulin syringe at home. Tool III: patient's practices of safe disposal of insulin syringe at home. Results: The findings of the present study indicated an improvement of the patient's knowledge, attitude and practice in various areas of patients' in various areas of safe disposal of insulin syringe after program implementation, this improvement was highly statistically significant $(\mathrm{p} \leq 0.01)$. Conclusion \&Recommendations: from the results of the present study, it can have concluded that the implementation of health program for diabetic patients about safe disposal of insulin syringe at home showed a remarkable improvement of the patient's level of knowledge, practice and attitude, it can be recommended that, there are obvious needs for health programs offered on simple media to diabetic patients to minimize wastes hazards.
\end{abstract}

Key word: health programs, diabetic patients, insulin syringe, sharps generated by non-clinical activities disposal. 


\section{INTRODUCTION}

Type 1 diabetes mellitus (T1DM) is an endocrine disorder characterized by absolute insulin deficiency secondary to pancreatic beta cell destruction from autoimmune or nonimmune factors, which results in abnormal macronutrient metabolism (Jones, Brashers, \& Huether, 2010).

Diabetes affects approximately 0.5 to $10 \%$ of the population depending on the type of diabetes, age group, and ethnic group. The prevalence of diabetes is increasing, particularly in the older age group and in developing countries. The number of individuals with diabetes is projected to reach 215 million by 2010. In western countries the overall prevalence is $4-6 \%$ and up to $10-12 \%$ among $60-70$ year olds. Most countries spend 6-12 of their annual health care budgets on diabetes and its consequences. Most of the morbidity and mortality is associated with Type 2, the prevalence rises to $20 \%$ in developing countries (World Health Organization) (Dunning T., 2009).

World Health Organization defined sharps as "items that could cause cuts or puncture wounds, including needles, hypodermic needles, scalpel and other blades, knives, infusion sets, saws, broken glass, and nails (WHO. 2004). Diabetes self-care involves self-administration of insulin and/or self-monitoring of blood glucose as a part of selfcare, various kinds of medical devices and instruments like insulin pens, needles, syringes, lancets, etc., are used by diabetes patients at home. Though proper disposal of sharps is important, mainly because of the more immediate and devastating consequences it can have on health of diabetic patient.

Sharps have been defined by World Health Organization as "items that could cause cuts or puncture wounds, including needles, hypodermic needles, scalpel and other blades, knives, infusion sets, saws, broken glass, and nails. World Health Organization; 2014 Though proper disposal of both sharps and plastics is important, this article will focus more on sharps, mainly because of the more immediate and devastating consequences it can have on human health.

Waste hazards prevention often called source reduction-means reducing waste by not producing it. Because waste prevention actually avoids waste generation, it is the preferred waste management activity. Overall, waste prevention conserves resources, 
protects the environment, and prevents the formation of greenhouse gaze (United States Environmental Protection Agency, 2002).

The primary sources of used sharps in the community are prescribed; self-injected medications and injected drugs of abuse. Over half of the estimated 3 billion annual injections can be attributed to insulin users. (Gold K, \& Schumann J., 2007).

Individual accidents and subsequent infections caused by infectious waste are well documented. The overall situation, however, remains difficult to assess, especially in developing countries. It is suspected that many cases of infection with a wide variety of pathogens have resulted from exposure to improperly managed infectious wastes in developing countries. (Alemayehu et al ,2005).

Proper disposal of used syringes and needles is essential to the prevention of inadvertent injuries from discarded needles. Injuries from contaminated needles and sharps present a concern in society today since they may increase risk for the transmission of blood-borne pathogens, such as human immunodeficiency virus, hepatitis B, and hepatitis. The primary sources of used sharps in the community are prescribed, self-injected medications and injected drugs of abuse. (Musselman et al, 2010).

Over half of the estimated 3 billion annual injections can be attributed to insulin users. Information regarding needlestick injuries among health care workers has been extensively reported. These injuries are not, however, limited to controlled healthcare environments, as sanitation workers, law enforcement personnel, and even children have been victims of needlestick injuries. Although these injuries are relatively rare with an incidence of less than $0.1 \%, 6,9$ community-based needlestick injuries are likely underreported. (Musselman et al., 2010)

The management of sharps is the responsibility of health care institutions whose health care workers (HCWs) routinely use them. In this setting, there are procedures and policies for the handling and disposal of sharps, but the same is not true in the community. The Philippines currently has no ordinances that regulate the disposal of sharps waste at the community level and poses a threat to public health and safety, 
and in particular, to garbage disposal workers. Discarded needles may expose waste workers to potential needle stick injuries and infection, since used needles can transmit diseases such as HIV and hepatitis B. (Quiwa \& Jimeno, 2014).

There are several ways to remove the cap from the needle but the most ideal and safest way to remove the cap is by carefully grasping the syringe and guiding the needle cap using the thumb and the pointing finger. Then gently push the cap away from the syringe to detach the cap from the hub. In this way needle stick injury can be prevented by avoiding the incidence of the rebound effect. Do not use the other hand as it increases the likeliness to have the syringe to rebound (Fred, 2012).

Factors that influenced the knowledge level of the respondents were analyzed, Practice of proper disposal, history of needle stick injury to self, college education, male sex and a higher attitude level were associated with a higher knowledge score but none of these reached statistical significance. (Quiwa \& Jimeno, 2014)

\section{Significance of the study}

A multi-country study among diabetics showed that proportion of various kinds of sharps thrown into the household bin varied from $46.9 \%$ to $67.6 \%$. Only in $<10 \%$ of cases, specific containers were used. Other developed countries have also showed improper sharp disposal practices among diabetes patients to be as high as $80-90 \%$. (Costello \& Parikh, 20013) and (Govender, 2012) A study from Pakistan showed that more than $90 \%$ patients discarded them into the household bin (Ishtiaq et al., 2012).

There is a lack of information on current practices on disposal of sharp household waste. So this study aimed to evaluate effect of health educational program for type 1 diabetic patients on their practices of on proper sharps disposal at home

\section{Specific Objectives:}

1. To assess the knowledge and attitude of type 1 diabetic patients toward proper sharps disposal before and after program implementation.

2. To assess the practices of type 1 diabetic patients toward proper sharps disposal before and after program implementation. 


\section{Hypotheses}

knowledge, attitude, and practice of type 1 diabetic patients about proper sharps disposal at home will be significantly improved after program implementation.

\section{SUBJECTS AND METHODS:}

\section{Study design:}

A quasi-experimental research design was used to carry this study.

\section{Study Setting:}

This study was conducted in four primary health care centers, representing the four district of Port-Said City, namely; El-Monakh, El-Kuwait, EL-arab, and Omar Ebn El-Kattab.

\section{Sample:}

All diabetic patients with type 1 diabetes mellitus attending the pre-mentioned setting in the period of three months were included in the study, total number were 100 patients.

\section{Tools:}

Data was collected by using three tools.

$\underline{\mathbf{1}^{\text {st}} \text { Tool: }}$ This tool is developed by Betkowitz, 1996.It included two parts:

\section{- Part 1: Socio-demographic Data:}

It contained information related to demographic characteristics of diabetic patients as sex, age, social status, education, and occupation.

- Part 2: Insulin waste disposal: it included items as:

How to remove their insulin wastes, numbers of wastes bin available at home, allocation of their wastes bin.

- Part 3: patient's knowledge of safe disposal of household sharp wastes management Questionnaire: 
It included question related to patient's knowledge towards wastes managements and its dangerousness and knowledge about safe disposal of insulin syringe \& related sharps at home.

$\underline{2^{\text {nd }} \text { Tool: }}$ An attitude scale, it developed by McConville et al., 2002, It included attitude of patients related to safe disposal of insulin syringe $\&$ related sharps at home, a 5-point sharps generated by non-clinical activities Likert scale was used to measure patient's attitude.

\section{3 $\underline{\text { rd Tool: }}$}

It developed by researchers, it is an observational checklist for patients' practices of safe disposal of household sharp wastes including insulin syringe.

\section{Scoring system:}

1. The total score of patient's knowledge towards safe disposal of insulin syringe $\&$ related sharps, it gives score 1 for correct answer and 0 for wrong or not known answer.

2. Score of patient's attitude towards wastes managements, it was ranking through using Likert scale from strongly agree to strongly disagree with five point for strongly agree, three point for agree, two for neutral, one for disagree answer and zero for strongly disagree answers.

3. Patient's practice scores towards safe disposal of insulin syringe \& related sharps, it gives score 1 for done correctly, and 0 score for done incorrectly and not done.

\section{Validity \& reliability}

For validity and clarity, the questionnaire was circulated to 3 content experts that included professors in medical surgical and community nursing professors and nursing education professor, and necessary modifications were done accordingly for comments, suggestions and necessary changes were incorporated with the help of advisor. In order to ensure questionnaire reliability, a pre-test was conducted in one of the selected clinic in Port Said. There were 30 subjects whose responses were pre tested for questionnaire using Cronbach alpha to test the internal reliability and consistency of questions for the knowledge and attitude section of the questionnaire 


\section{Pilot Study:}

After the development of the tools, a pilot study was carried out on $10 \%$ of the sample to ascertain the clarity and feasibility of the tool, to estimate the exact time needed for filling it up, and to detect any problems that might face the researcher and interfere with data collection. The questionnaire took 25- 30 minutes to be completed. After conducting the pilot study, minor necessary changes were done mainly in the form of rephrasing some sentences and changing some terms. The tool was then finalized. The pilot sample was not included in the main study sample.

Study maneuver: The study was conducted through four phases: assessment, program development, implementation, and evaluation. Collection of the data covered a period of three months from $15^{\text {th }}$ October 2015 to $15^{\text {th }}$ January 2016. Assessment phase: the participants were asked to fill the tools of knowledge and attitude, along with the instructions for filling it up, if the participant cannot read and write, the researchers were interviewing him, also an observational checklist was used to evaluate their practices related to wastes managements and safe disposal of household sharp waste including insulin syringe. The researchers were present all the time to respond to any raised queries. Program development phase: The researchers developed an educational program using the baseline information gathered in the assessment phase as well as the reviewed related literature. It was tailored to the identified needs and demands of patients in simple Arabic language. An instructional learning booklet was used as a handout to complement the health education sessions. The program included four sections cover all information about the disease and its management. Implementation phase: The participating patients were divided into ten groups; each group contain 10 patients. The health program was implemented for each group one session per week for a total of four sessions for each group and 40 sessions for all groups. The duration of the session was about two hours, and it carried at the pre-mentioned primary health care centers. The program was implemented with the principles of adult learning emphasizing active participation, interaction, and critical thinking. Different teaching methods were used such as mini lectures, group discussions, and demonstrations. The teaching media in included pamphlets, wall charts, and real objects prepared and used by the researcher, in addition to the booklet. Evaluation phase: The effectiveness of the program was evaluated twice after implementation using the same tools. 


\section{Administrative Considerations:}

The required official steps were taken to get the approval for carrying out the study from the local directorate of centers. Letters of agreement were issued to the headmasters of the selected centers from the directorate to conduct the study, and asking for cooperation with the researchers. Meetings were held with individual headmasters, where the researchers explained the purpose of the study and informed in order to obtain permission to include the diabetic patients on the present research.

Ethical considerations: The researchers explained the study aim and procedures to each potentially eligible diabetic patient. They informed them of their rights to refuse or withdraw at any time. Confidentiality of the data was ensured and the tools were anonymous.

\section{Statistical analysis}

Data were fed to the computer and analyzed using IBM SPSS software package version 20.0. (2) Qualitative data were described using number and percent. Quantitative data were described using mean and standard deviation. For normally distributed data, comparison between two independent populations were done using independent t-test while more than two populations were analyzed F-test (ANOVA) to be used and Post Hoc test (LSD) (Scheffe), also comparison between different periods using ANOVA with repeated measures and Post Hoc test was assessed using Bonferroni adjusted. Correlations between two quantitative variables were assessed using Pearson coefficient. For ordinal parameters correlations between two variables were assessed using Spearman coefficient.

\section{RESULTS:}

Table (1): Illustrated the Socio-demographic characteristics of diabetic patients. The table reveals that (38\%) of diabetic patients were from age group 30-40 years. on the other hands above half of them (59 \%) were male. finally, the $(33 \%)$ had read and write level of education. According to their marital status (59\%) were single, also, $(54 \%)$ of them house wife.

Table (2): Illustrates the change in the score of insulin dependent diabetic patient knowledge and their management related to proper waste disposal pre, post, and 
follow up phases' guideline. It indicates improvement of patients' knowledge in various areas of waste disposal and their total score through pre, post, follow up phases' guideline. From pre to where the mean percent change of improvement was $9.25 \pm 1.49$ and $11.38 \pm 1.20$, unfortunately this improvement was reduced from post to follow up of the program, where the mean percent change for knowledge was $29.01 \pm 94.86$ and for management was $-11.11 \pm 84.13$.

Table (3): This table shows the change in the score of insulin dependent diabetic patient attitude related to proper waste disposal pre, post, and follow-up phase's guideline. It revealed that improvement the attitude of patients was highly statistic significant $(\mathrm{p} \leq 0.01)$.

Table (4): Represents the change in the score of insulin dependent diabetic patient practices related to proper waste disposal pre, post, and follow-up phases' guideline. It indicates improvement of patients' practices in various areas of waste disposal and their total score through pre, post, follow up phases' guideline. This improvement was highly statistic significant $(\mathrm{p} \leq 0.01)$.

Table (5): Shows that there was a significant correlation between patients' knowledge, attitude and practice and their socio-demographic characteristics namely age, education in pre, post, and follow up of the program $p$ value $\leq 0.05$. The table also revealed that there was a significant correlation between patients' attitude and sex in pre, post, and follow up of the program, $\mathrm{p}$ value $\leq 0.05$, Moreover, there were a significant correlation between patients' practices, age and sex in pre, post, and follow up of the program, $p$ value $\leq 0.05$. 
Table (1): Distribution of the studied Sample according to their demographic data $(\mathrm{n}=100)$

\begin{tabular}{|c|c|c|c|}
\hline \multicolumn{2}{|c|}{ Item } & No. & $\%$ \\
\hline \multirow[t]{5}{*}{ Age (years) } & $30-40$ & 38 & 38.0 \\
\hline & $41-50$ & 35 & 35.0 \\
\hline & $>51$ & 27 & 27.0 \\
\hline & Min. - Max. & \multicolumn{2}{|c|}{$30.0-66.0$} \\
\hline & Mean \pm SD & \multicolumn{2}{|c|}{$\begin{array}{c}45.82 \pm \\
8.99\end{array}$} \\
\hline \multirow[t]{2}{*}{ Sex } & Male & 59 & 59.0 \\
\hline & Female & 41 & 41.0 \\
\hline \multirow[t]{4}{*}{ Marital status } & Single & 59 & 59.0 \\
\hline & Married & 19 & 19.0 \\
\hline & Divorced & 14 & 14.0 \\
\hline & Widow & 8 & 8.0 \\
\hline \multirow[t]{5}{*}{ Education } & Illiterate & 23 & 23.0 \\
\hline & Read and write & 33 & 33.0 \\
\hline & Secondary & 32 & 32.0 \\
\hline & University & 6 & 6.0 \\
\hline & Postgraduate & 6 & 6.0 \\
\hline \multirow[t]{5}{*}{ Occupation } & Housewife & 54 & 54.0 \\
\hline & Free works & 32 & 32.0 \\
\hline & $\begin{array}{l}\text { Governmental } \\
\text { workers }\end{array}$ & 10 & 10.0 \\
\hline & Private workers & 1 & 1.0 \\
\hline & Students & 3 & 3.0 \\
\hline
\end{tabular}


Table (2): Patient knowledge related to proper waste disposal pre, post, follow up phase's program $(\mathrm{n}=100)$

\begin{tabular}{|c|c|c|c|c|c|}
\hline Total score & Pre & Post & Follow up & $\mathbf{F}$ & $\mathbf{p}_{1}$ \\
\hline \multirow{2}{*}{$\begin{array}{l}\text { Waste } \\
\text { disposal } \\
\text { Min. - Max }\end{array}$} & & \multirow{3}{*}{$\begin{array}{c}6.0-12.0 \\
11.38 \pm \\
1.20\end{array}$} & \multirow{3}{*}{$\begin{array}{c}9.0-12.0 \\
12.0 \pm \\
11.43\end{array}$} & \multirow{3}{*}{$\begin{array}{c}130.88 \\
5^{*}\end{array}$} & \multirow{3}{*}{$\begin{array}{c}<0.001 \\
*\end{array}$} \\
\hline & $2.0-12.0$ & & & & \\
\hline Mean \pm SD & $9.25 \pm 1.49$ & & & & \\
\hline $\mathbf{p}_{2}$ & & $<0.001^{*}$ & $<0.001^{*}$ & & \\
\hline \multicolumn{6}{|l|}{$\begin{array}{l}\text { Types of } \\
\text { waste }\end{array}$} \\
\hline Min. - Max & & \multirow{2}{*}{$\begin{array}{c}4.0-5.0 \\
4.84 \pm \\
0.37\end{array}$} & & \multirow{2}{*}{$\begin{array}{c}274.88 \\
1^{*}\end{array}$} & \multirow{2}{*}{$\begin{array}{c}<0.001 \\
*\end{array}$} \\
\hline Mean \pm SD & $3.20 \pm 1.02$ & & $5.0 \pm 0.0$ & & \\
\hline $\mathbf{p}_{2}$ & & $<0.001^{*}$ & $<0.001^{*}$ & & \\
\hline \multicolumn{6}{|l|}{$\begin{array}{l}\text { Total } \\
\text { knowledge }\end{array}$} \\
\hline Min. - Max & $7.0-16.0$ & $\begin{array}{c}11.0- \\
17.0\end{array}$ & $\begin{array}{c}14.0- \\
17.0\end{array}$ & 337.72 & $<0.001$ \\
\hline Mean \pm SD & $\begin{array}{c}12.45 \pm \\
1.83\end{array}$ & $\begin{array}{c}16.22 \pm \\
1.24\end{array}$ & $\begin{array}{c}16.43 \pm \\
0.89\end{array}$ & $8^{*}$ & $*$ \\
\hline $\mathbf{p}_{2}$ & & $<0.001^{*}$ & $<0.001^{*}$ & & \\
\hline
\end{tabular}

F: F test (ANOVA)

$\mathrm{p} 1: \mathrm{p}$ value for $\mathrm{F}$ test (ANOVA) with repeated measures for comparing between different periods

p1: $p$-value for LSD for ANOVA with repeated measures for comparison between pre with each of post and follow up program

*: Statistically significant at $\mathrm{p} \leq 0.05$ 
Table (3): Patient attitude related to proper waste disposal pre, post, follow up phase's $\operatorname{program}(\mathrm{n}=100)$

\begin{tabular}{|c|c|c|c|c|c|}
\hline Total score & Pre & Post & Follow up & $\mathbf{F}$ & $\mathbf{p}_{1}$ \\
\hline $\begin{array}{l}\text { Attitude toward the sharp } \\
\text { household waste } \\
\text { Min. - Max } \\
\text { Mean } \pm \text { SD }\end{array}$ & $\begin{array}{c}34.0-54.0 \\
43.20 \pm \\
3.40\end{array}$ & $\begin{array}{c}38.0-50.0 \\
42.40 \pm \\
3.35\end{array}$ & $\begin{array}{c}36.0-48.0 \\
40.22 \pm \\
2.40\end{array}$ & $\begin{array}{c}27.06 \\
3^{*}\end{array}$ & $\begin{array}{c}<0.001 \\
*\end{array}$ \\
\hline $\mathbf{P}_{2}$ & & 0.093 & $<0.001^{*}$ & & \\
\hline $\begin{array}{l}\text { Precautions during injection } \\
\text { Min. - Max } \\
\text { Mean } \pm \text { SD }\end{array}$ & $\begin{array}{c}26.0-35.0 \\
30.24 \pm \\
3.02\end{array}$ & $\begin{array}{c}28.0-35.0 \\
31.65 \pm \\
1.97\end{array}$ & $\begin{array}{c}30.0-35.0 \\
32.09 \pm \\
1.16\end{array}$ & $\begin{array}{c}21.55 \\
8^{*}\end{array}$ & $\begin{array}{c}<0.001 \\
*\end{array}$ \\
\hline $\mathbf{p}_{2}$ & & $<0.001^{*}$ & $<0.001^{*}$ & & \\
\hline $\begin{array}{l}\text { Behavior on the disposal of } \\
\text { sharps waste } \\
\text { Min. - Max } \\
\text { Mean } \pm \text { SD }\end{array}$ & $\begin{array}{c}27.0-49.0 \\
36.61 \pm \\
6.14\end{array}$ & $\begin{array}{c}33.0-46.0 \\
39.70 \pm \\
2.75\end{array}$ & $\begin{array}{c}36.0-43.0 \\
39.07 \pm \\
1.44\end{array}$ & $\begin{array}{c}17.42 \\
5^{*}\end{array}$ & $\begin{array}{c}<0.001 \\
*\end{array}$ \\
\hline $\mathbf{p}_{2}$ & & $<0.001^{*}$ & $<0.001^{*}$ & & \\
\hline $\begin{array}{l}\text { Total attitude } \\
\text { Min. }- \text { Max } \\
\text { Mean } \pm \text { SD }\end{array}$ & $\begin{array}{c}98.0-135.0 \\
110.05 \pm \\
8.11\end{array}$ & $\begin{array}{c}105.0- \\
127.0 \\
113.75 \pm \\
5.78\end{array}$ & $\begin{array}{c}106.0- \\
121.0 \\
111.38 \pm \\
3.22\end{array}$ & $\begin{array}{c}11.25 \\
2^{*}\end{array}$ & $\begin{array}{c}<0.001 \\
*\end{array}$ \\
\hline $\mathbf{p}_{2}$ & & $<0.001^{*}$ & 0.177 & & \\
\hline
\end{tabular}

F: F test (ANOVA)

$\mathrm{p} 1$ : $\mathrm{p}$ value for $\mathrm{F}$ test (ANOVA) with repeated measures for comparing between different periods

p1: p-value for LSD for ANOVA with repeated measures for comparison between pre with each of post and follow up program

*: Statistically significant at $\mathrm{p} \leq 0.05$ 
Table (4): Patient practices related to proper waste disposal pre, post, follow up phase's program $(\mathrm{n}=100)$

\begin{tabular}{|c|c|c|c|c|c|}
\hline Total score & Pre & Post & Follow up & $\mathbf{F}$ & $\mathbf{p}_{1}$ \\
\hline \multicolumn{6}{|l|}{$\begin{array}{l}\text { Practice in dealing with } \\
\text { sharps waste }\end{array}$} \\
\hline Min. - Max & & $3.0-12.0$ & $8.0-32.0$ & 211.65 & $<0.001$ \\
\hline Mean \pm SD & $4.62 \pm 2.07$ & $\begin{array}{c}8.11 \pm \\
2.61\end{array}$ & $\begin{array}{c}11.95 \pm \\
3.29\end{array}$ & $6^{*}$ & * \\
\hline $\mathbf{p}_{2}$ & & $<0.001^{*}$ & $<0.001^{*}$ & & \\
\hline \multicolumn{6}{|l|}{$\begin{array}{l}\text { Practice in needle } \\
\text { /syringe disposal }\end{array}$} \\
\hline Min. - Max & $0.0-6.0$ & $1.0-12.0$ & $0.0-16.0$ & 28061 & $<00001$ \\
\hline Mean \pm SD & $2.16 \pm 1.09$ & $\begin{array}{l}6.36 \pm \\
4.12\end{array}$ & $\begin{array}{c}11.52 \pm \\
2.44\end{array}$ & & $*$ \\
\hline p2 & & $<0.001^{*}$ & $<0.001^{*}$ & & \\
\hline \multicolumn{6}{|l|}{ Total practice } \\
\hline Min. - Max & $2.0-14.0$ & $4.0-24.0$ & $8.0-44.0$ & & \\
\hline Mean \pm SD & $6.78 \pm 2.68$ & $\begin{array}{c}14.47 \pm \\
5.90\end{array}$ & $\begin{array}{c}23.47 \pm \\
4.70\end{array}$ & & $*$ \\
\hline $\mathbf{p}_{2}$ & & $<0.001^{*}$ & $<0.001^{*}$ & & \\
\hline
\end{tabular}

F: F test (ANOVA)

p1: $p$ value for $F$ test (ANOVA) with repeated measures for comparing between different periods

p1: p-value for LSD for ANOVA with repeated measures for comparison between pre with each of post and follow up program

*: Statistically significant at $\mathrm{p} \leq 0.05$ 
Table (5): correlation between patients' knowledge, attitude and practice with demographic data in pre, post, follow up phase's program $(n=100)$.

\begin{tabular}{|c|c|c|c|c|}
\hline & & Age & $\begin{array}{c}\operatorname{Sex} \\
(m=1 / f=2)\end{array}$ & Education \\
\hline Knowledge & & & & \\
\hline & $\mathbf{r}_{\mathbf{s}}$ & $\mathrm{r}=0.213^{*}$ & 0.040 & $-0.211^{*}$ \\
\hline 11- T Uat & $\mathbf{p}$ & $0.033^{*}$ & 0.695 & $0.035^{*}$ \\
\hline & $\mathbf{r}_{\mathrm{s}}$ & $r=0.094$ & -0.054 & $-0.291^{*}$ \\
\hline FIE - & $\mathbf{p}$ & 0.350 & 0.592 & $0.003^{*}$ \\
\hline$\overline{\text { Attitude }}$ & & & & \\
\hline & $\mathbf{r}_{\mathrm{s}}$ & $r=-0.099$ & $0.203^{*}$ & -0.022 \\
\hline 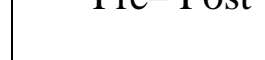 & $\mathbf{p}$ & 0.329 & $0.043^{*}$ & 0.830 \\
\hline DI & $\mathbf{r}_{\mathrm{s}}$ & $\mathrm{r}=-0.030$ & 0.187 & -0.037 \\
\hline & $\mathbf{p}$ & 0.766 & 0.063 & 0.714 \\
\hline Practice & & & & \\
\hline & $\mathbf{r}_{\mathrm{s}}$ & $\mathrm{r}=0.219^{*}$ & $0.413^{*}$ & 0.126 \\
\hline Pre- Post & $\mathbf{p}$ & $0.029^{*}$ & $<0.001^{*}$ & 0.211 \\
\hline$D_{m}$ & $\mathbf{r}_{\mathrm{s}}$ & $\mathrm{r}=0.264^{*}$ & $0.269^{*}$ & -0.189 \\
\hline $110-10$ & $\mathbf{p}$ & $0.008^{*}$ & $0.007^{*}$ & 0.060 \\
\hline
\end{tabular}

$\mathrm{r}$ : Pearson coefficient $\mathrm{r}_{\mathrm{s}}$ : Spearman coefficient $\quad *$ : Statistically significant at $\mathrm{p} \leq 0.05$ 


\section{DISCUSSION :}

Proper handling and disposal of bio-medical waste is very essential. Unfortunately, laxity and lack of adequate knowledge and practice on bio-medical waste disposal leads to staid health and environment apprehension. Furthermore, Musselman et al, 2010, added that, proper disposal of used syringes and needles is essential to the prevention of inadvertent injuries from discarded needles. Injuries from contaminated needles and sharps present a concern in society today since they may increase risk for the transmission of blood-borne pathogens, such as human immunodeficiency virus, hepatitis $\mathrm{B}$, and hepatitis. The primary sources of used sharps in the community are prescribed, self-injected medications and injected drugs of abuse.

Sharps waste is of great concern in developing and transitional regions of the world. Factors such as high disease prevalence and lack of health care professionals amplify the dangers involved with sharps waste. These factors make sharps disposal a pressing issue when addressing public health in these regions (Harner, 2004).

Comparison between pre, post and follow- up implementing health educational program regarding the diabetic patient's knowledge regarding insulin waste management, revealed that there were a statistically significance improvements through the three phases of the program. These findings goes in the same with PrussUstun,et al, 2003, who revealed that, the lack of easily accessible disposal options at the local community level is likely an issue contributing to the needle disposal problem, as is the lack of patient knowledge that these options exist. These must be designed in line current available resources and infrastructure.

Moreover, Wood et al, 2002 mentioned that there are some elements are essential to any client starting insulin therapy. These include the ability to self-inject insulin safely using a syringe or insulin pen.

The current study revealed that there was improvement of patients' practices in various areas of waste disposal and their total score through pre, post, follow up phases' guideline. This finding goes in the same way with Licy et al.,2013, who reported that study subjects have proper ideas and practice of waste segregation, conversion of waste to home compost $(p<0.05)$. Subjects are committed to minimize 
the wastes and to avoid throwing the wastes outside their houses $(p>0.05)$. In this point of view Pruss-Ustun et al, 2003, reported that, improper sharps management is a major factor involved in what is categorized as unsafe injections. Annually these account for 21 million, 2 million, and 260,000 of new HBV, HCV, and HIV infections annually. For each year, these infections are modeled to cost society over 270,000 lives between 2000 and 2030 .

However, Sharps waste is of great concern in developing and transitional regions of the world. The advances in sharps waste management made in developed countries have not been seen in these regions. Striking social and economic differences make implementing the same protocols and technologies unrealistic. In addition, factors such as high disease prevalence and lack of health care professionals amplify the dangers involved with sharps waste. These factors make sharps disposal a pressing issue when addressing public health in these regions. As with the rest of the world injection wastes make up the largest portion of sharps waste. However, injection use is much more prevalent in this world segment. One of the contributors to this increase is a larger emphasis placed on injections for therapeutic purposes. It has been estimated that $95 \%$ of all injections in developing regions are for therapeutic purposes. (Harner, 2004).

Moreover, Yale et al., 2002, reported that most people are able to safely and comfortably use short needle (in insulin syringe), they added that, all manufacturers recommend that needles be used only once to ensure sterility, prevent tissue damage, and to minimize the risk of bent or broken needles.

Based on the present study findings there were a statistically significant improvement in patients' attitude in various areas of waste disposal and their total score in post\& follow-up phases. this finding is in agreement with Licy C.D.et al., 2013, who found that, subjects have responded positively for minimizing the sharp house hold waste.

Despite much work on needle-free products for the administration of insulin, progress has been slow and inconsistent, and no significant needle-free alternative method of insulin administration is available. As needles will continue to be part of diabetic care by all patients requiring insulin for some time to come in Egypt and other countries, 
their safe disposal must therefore form an integral part of diabetic education (EcoDesk, 2014).

Finally, the current study revealed that the majority of diabetic patients haven't obtained any information from their doctors. And more than half reported that friends were the common source of information. In this regards, the most rapid improvements protocols and technologies must be developed specific for these regions. These must be designed in line current available resources and infrastructure. If tailored for these regions the sharps waste management methods rapid acceptance is more likely. (Pruss-Ustun et al., 2003).

Although this study's numbers are small and the results must be treated with caution, they suggest that appropriate education and knowledge on sharps disposal is the most important determining factor in correct disposal methods.

\section{CONCLUSION \& RECOMMENDATIONS:}

Based on the results of current study, it can be concluded that, the implementation of program for diabetic patients on home sharp disposal showed a remarkable increase and improvement of the patient's level of knowledge, practice and attitude. Significant association was found between influencing factors and level of practice on sharp waste disposal. So, the researchers recommended that there are needs for strategies and programs offered on simple media to diabetic patients to minimize wastes hazards, that take into consideration all the social, financial, literacy contexts.

\section{REFERENCE:}

Alemayehu, E; Tegegn, A; Beyene,G ; Workneh, D; Endale , H . (2005): Jimma University in collaboration with the Ethiopia Public Health Training Initiative, The Carter Center, the Ethiopia Ministry of Health, and the Ethiopia Ministry of Education

Berkowitz, K., Ernst, K., Dunbar, V. and Ziemer, D. (1996): Syringe disposal practices among insulin users (abstract). Diabetes Educ. 45 (suppl 1) 68A. 
Costello J, Parikh A. (2013): The sticking point: Diabetic sharps disposal practices in the community. J Gen Intern Med.; 28:868-9. [PMC free article] [PubMed]

Dunning T., (2009): Care of People with Diabetes: A Manual of Nursing Practice $3^{\text {rd }}$ Edition. Chichester. Wiley Blackwell.

Eco-Desk, L. (2014): Dispose of sharps through the Agency's Hazardous Waste programs: for residents \& businesses Local recycling and hazardous waste disposal information: www.recyclenow.org 565-3375.

Fred, G. (2012): "EPA issues new guidelines for sharps disposal". Retrieved 4 July p. 10

Gold K, Schumann J. (2007). Dangers of used sharps in household trash implications for home. Home Health Nurse; 25(9): 602-609. 3.

Govender D, Ross A. (2012). Sharps disposal practices among diabetic patients using insulin. S Afr Med J.; 102:163-4. [PubMed]

Harner, C. (2004): Needle Remover Device Design Transfer Package. Retrieved September 7, 2005.

Ishtiaq O, QadriAM, Mehar S, Gondal GM, Iqbal T, Ali S, et al. (2012): Disposal of syringes, needles, and lancets used by diabetic patients in Pakistan. J Infect Public Health.; 5:182-8. [ubMed]

Jones, R. E., Brashers, V. L., \& Heuther, S. E. (2010): Alterations of hormonal regulation. In K. L. McCance \& S. E. Huether, Pathophysiology: The biologic basis for disease in adults and children (6th ed., pp. 727-780). Maryland Heights, MO: Mosby Elsevier.

Licy C.D. Raghavan Vivek, Kamath Saritha, Anies T.K. and Josphina C.T. (2013): Awareness, Attitude and Practice of School Students towards Household Waste Management. Journal of Environment, Vol. 02, Issue 06, pp. 147-150 
McConville and E. M. Hamilton, (2002): "Syringe disposal practices and gender differences," The Diabetes Educator, vol. 28, no.1, pp.91-98.

Musselman, K.T; Sicat, P.L; Thomas, M.H; Harpe, S.E. (2010): Patients' Knowledge of and Practices Relating to the Disposal of Used Insulin Needles, Vol. 1, No. 2, Article 20 INNOVATIONS in pharmacy http://z.umn.edu/INNOVATIONS

Pruss-Ustun A, Rapiti E, Hutin Y (2003): Sharps injuries: global burden of disease from sharps injuries to health-care workers. Geneva. World Health Organization, (WHO Environmental Burden of Disease Series, No. 3). S1-S4.

Quiwa, L; Jimeno, C . (2014): Knowledge, Attitudes and Practices on the Disposal of Sharps in Patients of the UP-Philippine General Hospital, Diabetes Clinic Vol. 29 No. 2 November www.asean-endocrinejournal.org

United States Environmental Protection Agency, Solid Waste Management: A Local Challenge With Global Impacts, May 2002 www.epa.gov/globalwarming

WHO (World Health Organization) (2004): Proposed agenda to evaluate the risks and benefits associated with using needle-removing devices. Switzerland.

WHO (World Health Organization); 2014: [Last accessed on 2014 Dec14]. Safe management of wastes from health-care $2^{\text {nd }}$ ed. Geneva: Available from: http://apps.who.int/iris/bitstream/10665/85349/1/9789241548564_eng.pdf?ua1

Wood, L., Wilbourne, J., \&Kyne, G. D. (2002): Administration of insulin by injection. Practical Diabetes International Supplement, 19(Suppl. 2).

Yale, J. F., Begg, I., Gerstein, H., Houlden, R., Jones, H., Maheux, P. et al., (2002): 2001 Canadian Diabetes Association clinical practice guidelines for the prevention and management of hypoglycemia in diabetes. Canadian Journal of Diabetes 26, $22-$ 35. [On-line]. Available: www.diabetes.ca/Files/CDAHypoglycemiaGuidelines.pdf 


\title{
اثر برنامج تثقيف صحي لمرضى السكري النوع ( 1) عن ممارساتهم للتخلص السليم من حقن الأنسولين والأدوات الحادة في المنزل
}

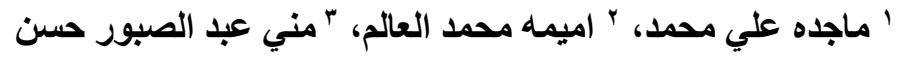 \\ ' r , r, ,
}

\section{الخلاصة}

إن التخلص الآمن للابر والحقن والأدوات الحادة الأخرى الناتجة عن الأنشطة غير السريرية هي قضية ناثـئة للمجالس المحلية. الهدف: كان الهدف من هذه الدر اسة لتقييم اثر برنـامج تثقيف صحي لمرضى السكري النوع ( ) عن ممارساتهم للتخلص السليم من حقن الأنسولين و الأدوات الحادة في المنزل طرق وأدوات البحث: تم استخدام التصميم شبه التجريبي في هذه الدر اسة. مكان البحث: أجريت هذه الدراسة في في

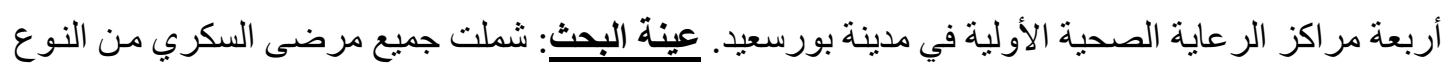
ا من داء السكري الذين حضروا الإعداد المذكورة مسبقا في فترة ثلاثة أثشر في الدراسة، وكان العدد الإجمالي • . . مريض. أدوات جمع البيانات: نم جمع البيانات باستخدام ثلاث أدوات بحثية الاداه الأولى: تتضمن البيانات الاجتماعية والديمو غر افية و المعرفة المريض من التخلص الآمن من حقنة الأنسولين في المنزل. أداة الثانيه:

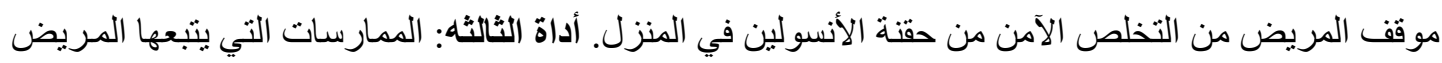
للتخلص الآمن من حقنة الأنسولين في المنزل. النتائج: بينت نتائج الدر اسة الحالية تحسنا في المعارف و المو اقف و الممارسات في مختلف المجالات من المرضى في مختلف مجالات التخلص الآمن من حقنة الأنسولين بعد تنفيذ

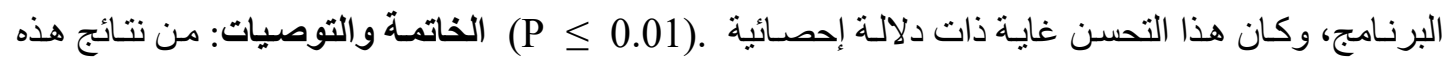

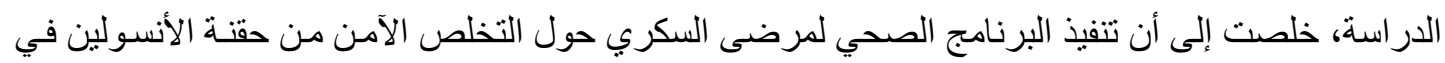

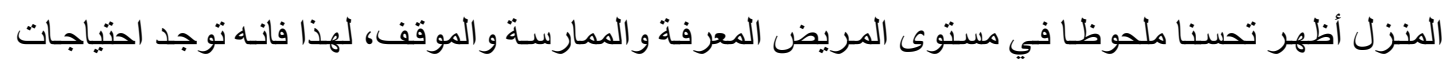
و اضحة لبر امج الصحة وعرضهها على وسـائل الإعلام بطريقه بسيطه لمرضى السكري للحد من المخاطر النفايات.

الكلمـات المرشـدة: برنـامج تثقيف صـحي ، مرضـى السكري، حقــة الأنسـولين، الأدوات الحسادة الناتجـه عن التخلص من الأنشطة غير السريرية. 